\title{
The Influence of Plant Growth Regulator and Rootstocks on Budding in Greenhouse Rose (Rosa hybrida L.) cv. First Red
}

\author{
Prabhjit Kaur*, H. S. Grewal, R. K. Dubey and K. K. Dhatt \\ Department of Floriculture and Landscaping, Punjab Agricultural University, \\ Ludhiana-141004, Punjab, India \\ *Corresponding author
}

K e y w o r d s
$\begin{aligned} & \text { Cytokinin, Rose, } \\ & \text { Rootstocks, Scion }\end{aligned}$
Article Info
$\begin{aligned} & \text { Accepted: } \\ & 23 \text { April } 2020 \\ & \text { Available Online: } \\ & \text { 10 May } 2020\end{aligned}$

\section{A B S T R A C T}

The study of different cytokinin treatments and rootstocks on budding in greenhouse cultivars of rose (Rosa hybrida L.) was conducted at Research farm of department of Floriculture and Landscaping, Punjab Agricultural University, Ludhiana (Punjab) during (2016-17). Three rootstocks ( $R$. indica, $R$. multiflora and $R$. bourboniana) and scion of cv. First Red were taken for the experiment and treated with different cytokinin (BAP) concentrations viz., $5 \mathrm{mg} \mathrm{L}^{-1}, 10 \mathrm{mg} \mathrm{L}^{-1}, 15$ $\mathrm{mg} \mathrm{L}^{-1}, 20 \mathrm{mg} \mathrm{L}^{-1}$ and control. The maximum sprouting (91.66 \%), survival (86.67 $\%)$, rooting $(95.00 \%)$, plant height $(23.01 \mathrm{~cm})$, shoot length $(15.01 \mathrm{~cm})$, number of branches (3.53), leaves (9.95) and flowers (2.21) per plant were significantly differed with rootstocks during both the year of experimentation. However, days to flower, bud emergence and full bloom were non-significant with cytokinin treatments in all the rootstocks. The BAP $20 \mathrm{mg} \mathrm{L}^{-1}$ and rootstock $R$. indica found best for all the parameters among all cytokinin treatments and rootstocks.

\section{Introduction}

Rose is a woody perennial of the genus Rosa in the family Rosaceae, having diverse growth habit, color, fragrance and blooming period. More than 2500 years ago, the poetess Sappho addressed the rose as 'The Queen of Flowers' (Muhammad et al., 1996). There are nearly 200 different species of rose and all the species are growing naturally in the temperate zones of the northern hemisphere along with sub temperate and sub-tropical areas. In India, area under rose cultivation was 30.87 thousand hectare producing 96.09 thousand tonnes loose flowers and 166.47 thousand tonnes cut stems (NHB, 2014).

The demand of plants for greenhouse varieties is always increasing, as more and more greenhouses are being established to meet the demand of flowers of retail florists and therefore, have a very good potential under 
Indian conditions. Since, the demand of high quality roses is increasing tremendously, it is essential to produce more number of plants locally for planting in the greenhouses under protected conditions. The conventional methods of propagation are cutting, budding, grafting and layering.

The hardwood cuttings and budding are the commercial methods to multiply the desirable rose varieties. Roses are usually propagated by $\mathrm{T}$ - budding, which has advantage for producing uniform plants, low chances of failure, low disease incidence and labour cost etc. In the North Indian conditions, Tbudding is done in December- March and plants become saleable in OctoberNovember, almost after two year of planting the rootstock.

This method is laborious as plants need to be taken care for two years and lot of space is required for propagation. The method of simultaneous budding i.e. cuttage-buddage method, has been reported successful for large scale propagation in one year to meet the demand of high quality rose plants. Assessment of response of different rootstocks used for propagation of commercial varieties is equally important as that of the scion varieties used for budding.

The rootstock used in rose influences the scion growth and development in various aspects. The differences in flower quality as influenced by rootstock have been reported earlier, while differences in color due to rootstock were found by De Vries and Dubois (1988).

The most commonly used rootstock includes $R$. canina inermis, Dr. Huey, $R$. multiflora, $R$ bourboniana, $R$. laxa, $R$. manetti, etc. Wholesale rose growers select rootstock based upon various characteristics, including ease of use and rate of success for field grown roses. In Punjab conditions, $R$. indica, $R$. bourboniana and $R$. multiflora are commonly used as rootstock for commercial propagation in roses. Plant growth regulators (PGRs) are organic substances that influence physiological processes of plants at extremely low concentrations (Zahir et al., 2001). These are either natural or synthetic compounds that are applied directly to a target plant to alter its life processes or its structure to improve quality, increase yield, or facilitate harvesting (Nickell, 1982).

There are five major classes of PGRs including auxins, gibberellins, cytokinins, abscisic acid and ethylene. Cytokinins are a class of plant hormones that influences many developmental processes including leaf senescence, apical dominance, chloroplast development, anthocyanin production and regulation of cell division (Rani Debi et al., 2005). Cytokinin, together with auxin plays an essential role in plant morphogenesis, having a profound influence on the formation of roots and shoots and their relative growth. Clarke et al., (1994) proposed that Cytokinin may inhibit the catalytic effects of ethylene on senescence at the level of its perception, as exogenous cytokinin had a stronger effect on the delay of senescence than did treatment with silver ions.

The two plant hormones ethylene and cytokinin are known to act antagonistically on harvest-induced senescence in broccoli: ethylene by accelerating the process and cytokinin by delaying it (Gapper et al., 2005). The significance of plant growth regulators for cut roses propagated by cuttage buddage method has hardly been investigated, although their application in cut roses has been successful. This study was carried out to investigate uses of preventing root senescence of and to evaluate the effect of cytokinin on the growth and yield of propagated greenhouse cut roses. 


\section{Materials and Methods}

The present investigation was carried out for two consecutive years of 2015-16 and 201617 at Research Farm of Department of Floriculture and Landscaping, Punjab Agricultural University, Ludhiana $\left(30^{\circ} 54^{\prime}\right.$ North latitude and $75^{\circ} 48^{\prime}$ East longitude with an altitude of 247 meters above the mean sea level), India. Ludhiana has sub-tropical and semi-arid climate with cold winters from November to January and mild climate during February and March.

Normal maximum and minimum temperatures vary from $21.6^{\circ} \mathrm{C}$ and $7.2^{\circ} \mathrm{C}$ in February, respectively. The corresponding figures for March, April and May are $26.6^{\circ} \mathrm{C}$ and $11.3^{\circ} \mathrm{C} ; 34.2^{\circ} \mathrm{C}$ and $16.9^{\circ} \mathrm{C}$; and $38.6^{\circ} \mathrm{C}$ and $21.9^{\circ} \mathrm{C}$, respectively. The normal relative humidity is $69.0 \%$ in February through 63, 47 and $39 \%$ in the months of March, April and May, respectively.

The experiment was laid out in factorial CRD (Completely Randomized Design). The experiment comprised one genotype (First Red) and three rootstocks ( $R$. indica, $R$. multiflora and $R$. bourboniana) of rose. The mature shoots ( $>1 \mathrm{yr}$ old) used for making the stem cuttings for using as rootstock. The cuttings (8-9 inches long, pencil thickness) of rootstocks were budded with the scion bud of First Red.

The scion buds were treated with BAP concentrations viz., $5 \mathrm{mg} \mathrm{L}^{-1}, 10 \mathrm{mg} \mathrm{L}^{-1}, 15$ $\mathrm{mg} \mathrm{L}^{-1}$ and $20 \mathrm{mg} \mathrm{L}^{-1}$. These budded cuttings were then dipped in IBA solution of $1500 \mathrm{mg}$ $\mathrm{L}^{-1}$ and then planted in sand with control in three replications with ten plants per replication in December- February. The observations were recorded as per cent sprouting, rooting, survival of budded cuttings, plant height $(\mathrm{cm})$, shoot length $(\mathrm{cm})$ and number of branches, leaves, flowers per plant, days to flower bud emergence and full bloom. The statistical analysis was performed using SAS software and treatment means were compared using Duncan Multiple Range Test (DMRT) at 5\% level of significance (Duncan 1955).

\section{Results and Discussion}

The effect of different rootstocks on growth parameters of simultaneously budded cuttings of rose is presented in Table 1, 2, $3 \& 4$. The performance of different characters viz., per cent sprouting, rooting, survival, shoot length and number of branches per plant were significantly improved by using the different concentrations of cytokinin.

The sprouting of the cuttings found significantly better in all the treatments than the control (Table 1). The best treatment for sprouting was treatment T4 (BAP $20 \mathrm{mg} \mathrm{L}^{-1}$ ) in all the rootstocks. On averaging across the years the highest sprouting (91.66\%) was observed in T4 (BAP $20 \mathrm{mg} \mathrm{L}^{-1}$ ) in R. indica, whereas, the treatment $\mathrm{T} 1$ (BAP $5 \mathrm{mg} \mathrm{L}^{-1}$ ) and treatment T2 (BAP $10 \mathrm{mg} \mathrm{L}^{-1}$ ) were at par. The lowest sprouting was observed in $R$. bourboniana as 41.67 .

Similarly, Swarup and Malik (1974) observed that the bud take varied with the type of rootstock used. The percentage of bud take on $R$. indica var odorata was the highest in Super Star (100), Dr Homi Bhaba (88) and Pusa Sonia (80) while bud take of Queen Elizabeth was highest (96) on R. multiflora.

Some cultivars gave equally good results on two different rootstocks, McGredys Sunset on Edouard and $R$. multiflora, McGredys Yellow on Edouard and $R$. indica var odorata and Happiness on $R$. indica var odorata and $R$. multiflora. The maximum bud survival found in the treatment T4 (BAP $20 \mathrm{mg} \mathrm{L}^{-1}$ ), in all rootstocks (Table 1). 
The highest survival of budded cuttings $(86.67 \%$ ) was observed in T4 (BAP $20 \mathrm{mg}$ $\left.\mathrm{L}^{-1}\right)$. The cytokinin plays an important role to improve the bud take and bud break, which proceeds to the plant survival (Wickson and Thimman, 1958). The role of BAP treatments in bud union and bud break might be due to the promotion of cell division and growth. The bud union is directly related to the plant survival. Bud break effect of cytokinins has been reported by Carpenter and Rodrigues (1971), Okhawa (1980).

On averaging across the two years the maximum rooting $(81.67 \%)$ was observed in rootstock $R$. indica which was at par with $R$. multiflora $(79.33 \%)$. Among the rootstocks the rooting was lowest $(73.00 \%)$ in $R$. bourboniana (Table 1). Likewise, Singh et al., (2011) observed stionic effect of rootstocks ( $R$. multiflora, $R$. indica var. odorata, $R$. witchuriana and $R$. bourboniana) on different rose cultivars and $R$. indica var. odorata was found superior with respect to root parameters (days to root initiation, percentage of rooted cuttings, number of roots per cutting and length of root).

The results are in line with Malik (1980) where $R$. indica var. odorata was the best rootstock than $R$. bourboniana and $R$. muliflora for grafted plants. Similarly, Randhawa and Mukhopadhyay (1986) also reported that $R$. indica var. odorata was better rootstock due to resistance to powdery mildew and better suitability to North Indian conditions. In all the treatments the rooting of cutting was non-significant but rooting was significantly higher than the control (T5).

This indicates that the cytokinin concentration used in experiment did not hinder the auxin concentration used in experiment. However, the highest rooting $(95.00 \%)$ was found in $R$. indica in T4 (BAP $20 \mathrm{mg} \mathrm{L}^{-1}$ ). The lowest rooting $(41.67 \%)$ across the years was found in T5 (control) in $R$. bourboniana. The rootstocks had significant effect on plant height and data was recorded after three months of planting of the budded cuttings (Table 2). On averaging across the years the maximum plant height was $17.34 \mathrm{~cm}$ in $R$. indica. Among all rootstocks the lowest plant height $(14.09 \mathrm{~cm})$ observed in $R$. bourboniana.

The maximum plant height in $R$. indica was probably due to the better root growth of the cuttings, which helps in the absorption of the nutrients and assimilate them to the upper part of the cuttings which leads to the more plant growth. The plant height of the plants of First Red was also significantly differed by the different concentrations of the BAP and significantly higher than the control. The treatment T4 (BAP $20 \mathrm{mg} \mathrm{L}^{-1}$ ), found best among all BAP treatments for plant height.

The highest plant height on averaging across the years among all treatments was $23.01 \mathrm{~cm}$ in $R$. indica in T4 (BAP $20 \mathrm{mg} \mathrm{L}^{-1}$. In $R$. bourboniana the lowest plant height $(8.13$ $\mathrm{cm})$ observed in T5. Along the rootstock performance the Cytokinin involvement in cell division and cell growth also leads to increase in plant height. The shoot length of the plants of cv. First Red was recorded after three months of planting of the budded cuttings. The shoot length was found significantly influenced by the different rootstocks (Table 2). Among the rootstocks, the highest shoot length was observed (11.22 $\mathrm{cm})$ in $R$. indica.

However, the minimum shoot length (7.97 $\mathrm{cm}$ ) found in $R$. bourboniana, on averaging across the years. The influence of rootstocks on shoot growth has been studied by various workers like Swarup and Malik (1974), Pandey and Sharma (1976) and Sharma (1979). The performance of rose cultivars may depend much on the rootstock used; 
however, the performance of cultivars on particular rootstock may be suitable for a particular locality and may not perform well in another (Karadi and Patil, 2006). The maximum shoot length was observed in $R$. indica which is probably due to their better root growth. The shoot length of the plants of cv. First Red was also found significantly influenced by the BAP concentrations.

The treatment T4 (BAP $20 \mathrm{mg} \mathrm{L}^{-1}$ ) was found best among the different treatments in all rootstocks. The highest shoot length was $15.01 \mathrm{~cm}$ in $R$. indica in T4 (BAP $20 \mathrm{mg} \mathrm{L}^{-1}$ ). The lowest shoot length $(4.53 \mathrm{~cm})$ found in T5 (control) in $R$. bourboniana. The role of BAP in increasing the shoot length can be attributed to the involvement of cytokinin in cell growth and cell differentiation.

In this study, it was observed that number of branches per plant varied significantly among the rootstocks after three months of planting of the budded cuttings (Table 3). On averaging across the years the maximum number of branches per plant (2.13) was found in $R$. indica and minimum was in $R$. bourboniana. The number of branches per plant was also significantly influenced by the different concentrations of the BAP. The treatment T4 (BAP $20 \mathrm{mg} \mathrm{L}^{-1}$ ) found the best among all treatments of BAP among all rootstocks. The highest number of branches per plant was 3.53 in T4 (BAP $20 \mathrm{mg} \mathrm{L}^{-1}$ ) in $R$. indica. However, the minimum number of branches per plant (1.00) found in control (T5) in $R$. bourboniana. The number of branches in BAP treated plants may be due to the ability of cytokinin to reducing the apical dominance and producing adventitious shoots in plants. Leaves are important organ for the photosynthesis in plants, more number of leaves leads to more photosynthetic efficiency which results to the biomass and flower production in plants. The effect of rootstock on number of leaves per plant was recorded after three months of planting in Table 3. Among the all rootstocks the maximum number of leaves per plant was 7.39 in $R$. indica which were significantly higher than other rootstocks. The BAP treatments showed conspicuous effect on number of leaves per plant than control. The highest number of leaves (9.95) recorded in $R$. indica in T4 (BAP $20 \mathrm{mg} \mathrm{L}^{-1}$ ). The more number of leaves are due to the more number of branches and height of the plant. The numerous and vigorous root system leads to the better foliage of the plant. Cytokinin retarded the leaf senescence and this leads to presence of more number of leaves at a particular time. The lowest number of leaves per plant was 4.21 in T5 (control) in $R$. bourboniana.

The data presented in table 4 showed significant difference for the number of flowers per plant. The maximum number of flowers per plant (1.50) was observed in $R$. indica among all the rootstocks. The present results are with conformity of the observation of Goujan (1974). He found that cvs. Carina, Lara, Super Star and Zorina produced more flowers per plant on $R$. indica var. major. Similarly, Malik (1980) reported that rose cv. Sonia produced more number of marketable blooms when budded on $R$. indica rootstock than own rooted plants. Mukhopadhyay and Bankar (1986) reported that thornless rootstock produced maximum number of flowers followed by $R$. multiflora and $R$. indica. The treatments showed conspicuous effect on number of flowers per plant than control. There was significant difference among treatments of BAP for number of flowers per plant. The highest number of flowers (2.21) was recorded in $R$. indica in $\mathrm{T} 4$ (BAP $20 \mathrm{mg} \mathrm{L}^{-1}$ ). The lowest number of flowers per plant (1.00) found in T5 (control) in $R$. bourboniana. The days to flower bud emergence and days to full bloom recorded non-significant among the rootstocks and different treatments of BAP. 
Table.1 Effect of cytokinin treatment on growth parameters of budded cuttings in Rosa hybrida L. cv. First Red

\begin{tabular}{|c|c|c|c|c|c|c|c|c|c|}
\hline $\begin{array}{l}\text { Treatment/ } \\
\text { rootstock }\end{array}$ & $\begin{array}{c}R . \\
\text { indica }\end{array}$ & $\begin{array}{c}R . \\
\text { multiflora }\end{array}$ & $\begin{array}{c}R . \\
\text { bourboniana }\end{array}$ & $\begin{array}{c}R . \\
\text { indica }\end{array}$ & $\begin{array}{c}R . \\
\text { multiflora }\end{array}$ & $\begin{array}{c}R . \\
\text { bourboniana }\end{array}$ & $\begin{array}{c}R . \\
\text { indica }\end{array}$ & $\begin{array}{c}R . \\
\text { multiflora }\end{array}$ & $\begin{array}{c}R . \\
\text { bourboniana }\end{array}$ \\
\hline & \multicolumn{3}{|c|}{ Per cent Sprouting } & \multicolumn{3}{|c|}{ Per cent Survival } & \multicolumn{3}{|c|}{ Per cent rooting } \\
\hline T1 & 65.00ac & $60.00 \mathrm{bc}$ & $50.00 \mathrm{cc}$ & $60.00 \mathrm{ac}$ & $55.00 \mathrm{bc}$ & $41.67 \mathrm{cc}$ & $85.00 \mathrm{aa}$ & 81.67aa & $75.00 \mathrm{ba}$ \\
\hline T2 & $66.67 \mathrm{ac}$ & $65.00 \mathrm{bc}$ & $50.00 \mathrm{cc}$ & $65.00 \mathrm{ac}$ & $63.33 b c$ & $43.33 \mathrm{cc}$ & $85.00 \mathrm{aa}$ & $85.00 \mathrm{aa}$ & $78.34 \mathrm{ba}$ \\
\hline T3 & $85.00 \mathrm{ab}$ & $71.33 \mathrm{bb}$ & $51.67 \mathrm{cb}$ & $75.00 \mathrm{ab}$ & $71.33 \mathrm{bb}$ & $51.67 \mathrm{cb}$ & $91.67 \mathrm{aa}$ & 95.00aa & $80.00 \mathrm{ba}$ \\
\hline T4 & $91.66 \mathrm{aa}$ & $80.00 \mathrm{ba}$ & $68.33 \mathrm{ca}$ & $86.67 \mathrm{aa}$ & $75.00 \mathrm{ba}$ & $63.33 \mathrm{ca}$ & $95.00 \mathrm{aa}$ & $86.67 a a$ & $81.67 \mathrm{ba}$ \\
\hline T5 & $51.67 \mathrm{ad}$ & $48.33 \mathrm{bd}$ & $41.67 \mathrm{~cd}$ & $48.00 \mathrm{ad}$ & $41.67 \mathrm{bd}$ & $38.33 \mathrm{cc}$ & $51.67 \mathrm{aa}$ & $48.34 \mathrm{ab}$ & $41.67 \mathrm{bb}$ \\
\hline Mean & $67.33 \mathrm{a}$ & $65.00 \mathrm{~b}$ & $54.34 \mathrm{c}$ & $67.33 a$ & $62.12 b$ & $47.67 \mathrm{c}$ & $81.67 \mathrm{a}$ & $79.33 a$ & $73.00 \mathrm{~b}$ \\
\hline F-test & $*$ & $*$ & $*$ & $*$ & $*$ & $*$ & $*$ & $*$ & $*$ \\
\hline
\end{tabular}

T1- BAP $5 \mathrm{mg} \mathrm{L}^{-1}, \mathrm{~T}_{2}$ - BAP $10 \mathrm{mg} \mathrm{L}^{-1}, \mathrm{~T}_{3}$ - BAP $15 \mathrm{mg} \mathrm{L}^{-1}, \mathrm{~T}_{4}$ - BAP $20 \mathrm{mg} \mathrm{L}^{-1}$, Control,

Mean values in each column with the same letter are not significantly different at $\mathrm{p}<0.05$ according to DMRT.

ns $=$ non-significant $*$ Significant at $\mathrm{p}<0.05$

Table.2 Effect of cytokinin treatment on growth parameters of budded cuttings in Rosa hybrida L. cv. First Red

\begin{tabular}{|c|c|c|c|c|c|c|}
\hline \multirow[t]{2}{*}{$\begin{array}{l}\text { Treatment/ } \\
\text { rootstock }\end{array}$} & $\begin{array}{c}R . \\
\text { indica }\end{array}$ & $\begin{array}{c}R . \\
\text { multiflora }\end{array}$ & $\begin{array}{c}R . \\
\text { bourboniana }\end{array}$ & $\begin{array}{c}R . \\
\text { indica }\end{array}$ & R. multiflora & $\begin{array}{c}R . \\
\text { bourboniana }\end{array}$ \\
\hline & \multicolumn{3}{|c|}{ Plant height (cm) } & \multicolumn{3}{|c|}{ Shoot length (cm) } \\
\hline T1 & $14.37 \mathrm{ad}$ & $13.81 \mathrm{bd}$ & $12.90 \mathrm{~cd}$ & $8.47 \mathrm{ad}$ & $7.91 \mathrm{bd}$ & $7.00 \mathrm{~cd}$ \\
\hline $\mathbf{T 2}$ & $17.91 \mathrm{ac}$ & $16.81 b c$ & $14.62 \mathrm{cc}$ & $11.61 \mathrm{ac}$ & $10.51 b c$ & $8.32 \mathrm{cc}$ \\
\hline T3 & $20.32 \mathrm{ab}$ & $18.42 \mathrm{bb}$ & $16.80 \mathrm{cb}$ & 13.52ab & $11.62 \mathrm{bb}$ & $9.45 \mathrm{cb}$ \\
\hline T4 & 23.01aa & $20.39 \mathrm{ba}$ & $18.03 \mathrm{ca}$ & $15.01 \mathrm{aa}$ & $12.39 \mathrm{ba}$ & $10.16 \mathrm{ca}$ \\
\hline T5 & $11.10 \mathrm{ae}$ & $9.14 \mathrm{be}$ & $8.13 \mathrm{ce}$ & $7.5 \mathrm{ae}$ & 5.54 be & $4.53 \mathrm{ce}$ \\
\hline Mean & $17.34 \mathrm{a}$ & $15.71 \mathrm{~b}$ & $14.09 \mathrm{c}$ & $11.22 \mathrm{a}$ & $9.59 \mathrm{~b}$ & $7.97 \mathrm{c}$ \\
\hline F-test & $*$ & $*$ & $*$ & $*$ & $*$ & $*$ \\
\hline
\end{tabular}

T1- BAP $5 \mathrm{mg} \mathrm{L}^{-1}, \mathrm{~T}_{2}$ - BAP $10 \mathrm{mg} \mathrm{L}^{-1}, \mathrm{~T}_{3}$ - BAP $15 \mathrm{mg} \mathrm{L}^{-1}, \mathrm{~T}_{4}$ - BAP $20 \mathrm{mg} \mathrm{L}^{-1}$, Control,

Mean values in each column with the same letter are not significantly different at $\mathrm{p}<0.05$ according to DMRT; ns = non-significant $*$ Significant at $\mathrm{p}<0.05$

Table.3 Effect of cytokinin treatment on growth parameters of budded cuttings in Rosa hybrida L. cv. First Red

\begin{tabular}{|c|c|c|c|c|c|c|}
\hline \multirow{2}{*}{$\begin{array}{l}\text { Treatment/ } \\
\text { rootstock }\end{array}$} & $\begin{array}{c}\boldsymbol{R} \text { indica } \\
\text { Number of branches per plant }\end{array}$ & $\begin{array}{c}\boldsymbol{R} . \\
\text { multiflora }\end{array}$ & $\begin{array}{c}\boldsymbol{R} . \\
\text { bourboniana }\end{array}$ & $\begin{array}{c}\boldsymbol{R} . \\
\text { indica }\end{array}$ & $\begin{array}{c}\boldsymbol{R} . \\
\text { multiflora }\end{array}$ & $\begin{array}{c}\boldsymbol{R} . \\
\text { bourboniana }\end{array}$ \\
\hline & \multicolumn{2}{|c|}{ Number of leaves per plant } \\
\hline T1 & $1.54 \mathrm{ac}$ & $1.46 \mathrm{bc}$ & $1.26 \mathrm{cc}$ & $6.21 \mathrm{ad}$ & $5.33 \mathrm{bd}$ & $5.79 \mathrm{bd}$ \\
\hline T2 & $1.72 \mathrm{ac}$ & $1.54 \mathrm{bc}$ & $1.36 \mathrm{cc}$ & $7.46 \mathrm{ac}$ & $7.52 \mathrm{bc}$ & $6.51 \mathrm{bc}$ \\
\hline T3 & $2.70 \mathrm{ab}$ & $2.05 \mathrm{bb}$ & $1.88 \mathrm{cb}$ & $7.92 \mathrm{ab}$ & $7.60 \mathrm{bb}$ & $7.17 \mathrm{bb}$ \\
\hline T4 & $3.53 \mathrm{aa}$ & $3.09 \mathrm{ba}$ & $2.79 \mathrm{ca}$ & $9.95 \mathrm{aa}$ & $8.29 \mathrm{ba}$ & $7.84 \mathrm{ba}$ \\
\hline T5 & $1.16 \mathrm{ad}$ & $1.09 \mathrm{bd}$ & $1.00 \mathrm{~cd}$ & $5.41 \mathrm{ae}$ & $4.34 \mathrm{be}$ & $4.21 \mathrm{be}$ \\
\hline Mean & $2.13 \mathrm{a}$ & $1.85 \mathrm{~b}$ & $1.66 \mathrm{c}$ & $7.39 \mathrm{a}$ & $6.61 \mathrm{~b}$ & $6.30 \mathrm{~b}$ \\
\hline F-test & $*$ & $*$ & $*$ & $*$ & $*$ & $*$ \\
\hline
\end{tabular}

T1- BAP $5 \mathrm{mg} \mathrm{L}^{-1}, \mathrm{~T}_{2}$ - BAP $10 \mathrm{mg} \mathrm{L}^{-1}, \mathrm{~T}_{3}$ - BAP $15 \mathrm{mg} \mathrm{L}^{-1}, \mathrm{~T}_{4}$ - BAP $20 \mathrm{mg} \mathrm{L}^{-1}$, Control,

Mean values in each column with the same letter are not significantly different at $\mathrm{p}<0.05$ according to DMRT.

ns $=$ non-significant $*$ Significant at $\mathrm{p}<0.05$ 
Table.4 Effect of cytokinin treatment on floral parameters of budded cuttings in Rosa hybrida L. cv. First Red

\begin{tabular}{|c|c|c|c|c|c|c|c|c|c|}
\hline \multirow[t]{2}{*}{$\begin{array}{l}\text { Treatment/ } \\
\text { rootstock }\end{array}$} & $\begin{array}{c}R . \\
\text { indica }\end{array}$ & $\begin{array}{c}R . \\
\text { multiflora }\end{array}$ & $\begin{array}{c}R . \\
\text { bourboniana }\end{array}$ & $\begin{array}{c}R . \\
\text { indica }\end{array}$ & $\begin{array}{c}R . \\
\text { multiflora }\end{array}$ & $\begin{array}{c}R . \\
\text { bourboniana }\end{array}$ & $\begin{array}{c}R . \\
\text { indica }\end{array}$ & $\begin{array}{c}R . \\
\text { multiflora }\end{array}$ & $\begin{array}{c}R . \\
\text { bourboniana }\end{array}$ \\
\hline & \multicolumn{3}{|c|}{ Number of flowers per plant } & \multicolumn{3}{|c|}{ Days to flower bud emergence } & \multicolumn{3}{|c|}{ Days to full bloom } \\
\hline T1 & $1.15 \mathrm{ac}$ & $1.06 \mathrm{bc}$ & $1.04 \mathrm{cc}$ & $55.25 \mathrm{aa}$ & 54.94aa & $54.86 \mathrm{aa}$ & 63.39aa & $62.99 \mathrm{aa}$ & 64.63aa \\
\hline T2 & $1.49 \mathrm{ab}$ & $1.32 \mathrm{bb}$ & $1.14 \mathrm{cb}$ & $53.85 \mathrm{aa}$ & $51.68 \mathrm{aa}$ & $54.51 \mathrm{aa}$ & 64.71 aa & 63.78aa & 65.51 aa \\
\hline T3 & $1.76 \mathrm{ab}$ & $1.60 \mathrm{bb}$ & $1.28 \mathrm{cb}$ & $51.65 \mathrm{aa}$ & $52.64 \mathrm{aa}$ & $54.52 \mathrm{aa}$ & $61.83 \mathrm{aa}$ & 60.69aа & $64.36 \mathrm{aa}$ \\
\hline T4 & $2.21 \mathrm{aa}$ & $2.16 \mathrm{ba}$ & $1.95 \mathrm{ca}$ & $50.44 a a$ & $50.47 \mathrm{aa}$ & $51.71 \mathrm{aa}$ & 60.54aa & 60.92aa & 64.38aa \\
\hline T5 & $1.02 \mathrm{ac}$ & $1.02 \mathrm{bc}$ & $1.00 \mathrm{cc}$ & $53.78 \mathrm{aa}$ & $56.83 \mathrm{aa}$ & $58.28 \mathrm{aa}$ & 65.64aa & 66.38aa & 68.85aa \\
\hline Mean & $1.50 \mathrm{a}$ & $1.42 \mathrm{~b}$ & $1.28 \mathrm{c}$ & $53.56 \mathrm{a}$ & $53.35 \mathrm{a}$ & $54.76 \mathrm{a}$ & $63.22 \mathrm{a}$ & $62.95 \mathrm{a}$ & $65.55 \mathrm{a}$ \\
\hline F-test & * & * & * & ns & ns & ns & ns & ns & ns \\
\hline
\end{tabular}

T1- BAP $5 \mathrm{mg} \mathrm{L}^{-1}, \mathrm{~T}_{2}$ - BAP $10 \mathrm{mg} \mathrm{L}^{-1}, \mathrm{~T}_{3}$ - BAP $15 \mathrm{mg} \mathrm{L}^{-1}, \mathrm{~T}_{4}$ - BAP $20 \mathrm{mg} \mathrm{L}^{-1}$, Control,

Mean values in each column with the same letter are not significantly different at $\mathrm{p}<0.05$ according to DMRT.

ns $=$ non-significant $*$ Significant at $\mathrm{p}<0.05$

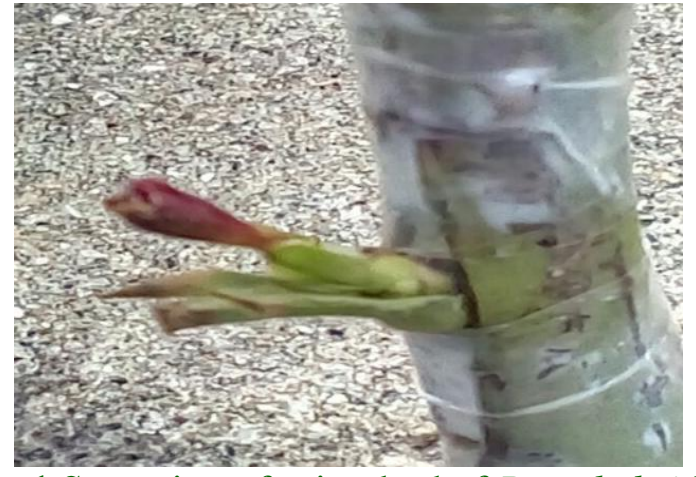

Fig.1 Sprouting of scion bud of Rosa hybrid L cv. First Red on rootstock $R$. indica

In conclusion, the rootstock $R$. indica (Fig. 1) found best for the budding of the greenhouse rose cultivar First Red in Punjab conditions. Among the cytokinin treatments the best treatment for vegetative and floral parameters was BAP $20 \mathrm{mg} \mathrm{L}^{-1}$ (Fig. 2)

\section{References}

Clarke, S. F., Jameson, P. E., and Downs, C. 1994. The influence of 6benzylaminopurine on post-harvest senescence of floral tissues of broccoli (Brassica oleracea var. Italica). J Plant Growth Regul. 14:21-27.

Carpenter, W. J., and Rodriguez, R. C. 1971. The effect of plant growth regulating chemicals on rose shoot development

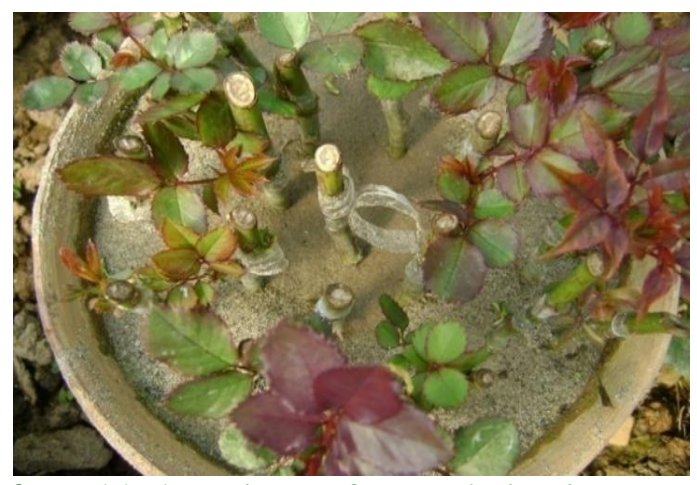

Fig.2 Budded cuttings of Rosa hybrid L. cv. First Red (BAP $20 \mathrm{mg} \mathrm{L}^{-1}$ )

from basal and axillary buds. J Am Soc Hort Sci. 96: 389-391.

De Varies, P., and Dubois. 1990. Shoot production of 'Sonia' on hybrid tea rootstock clones of different vigour. Gartenabuwissenschaft. 55: 268-271.

Duncan, D. B. 1955. Multiple range and multiple F tests. Biometrics. 11: 1-42.

Gapper, N. E., Coupe, S. A., McKenzie, M. J., Sinclair, B. K., Lill, R. E., and Jameson, P. E. 2005. Regulation of harvest- induced senescence in broccoli (Brassica oleracea var. italica) by cytokinin, ethylene, and sucrose. J Plant Growth Regul. 24:153-165.

Goujan, C. 1974. Research on greenhouse rose stocks. Acta hort. 43: 161-165.

Karadi, R. V., and Patil, V. S. 2006. Influence 
of rootstocks on bud take, growth and flowering of rose cultivars. J Orn Hort. 9: 126-129.

Malik, R. S. 1980. Studies on production of rose for cut flowers. Proc National Seminar on Production Technology for Commercial Flower Crops, Tamil Nadu Agricultural University, Coimbatore, India, pp: 51-54.

Muhammad, S. M., Hiroyasu, S., and Shahzad, N. 1996. Diversity in Roses. National Agricultural Research Center, Islamabad, pp: 1-2.

Mukhopadhyay, A., and Bankar, G. J. 1986. Comparative performance of new thornless rose rootstock with few scion cultivars. Indian J Hort. 43: 144-147.

NHB. 2014. National Horticulture Board, Indian Horticulture Database. www.nhb.gov.in.

Nickell, L. G. 1982. Plant growth regulators: agricultural uses, Springer, New York, p. 173.

Ohkawa, K. 1980. Cutting grafts as a means to propagate greenhouse roses. Sci Hort.
13:191-199.

Pandey, D. S., and Sharma, R. K. 1976. Studies on the performance of rose varieties on different rootstocks in Allahabad. Pl Sci. 8: 88-92.

Rani Debi, B., Taketa, S., and Ichii, M. 2005. Cytokinin inhibits lateral root initiation but stimulates lateral root elongation in rice (Oryza sativa). Plant Physiol. 162:507-515.

Sharma, S. S. 1979. Nursery performance of rose rootstocks. Haryana J Hort Sci. 8: 220-222.

Swarup, V., and Malik, R. S. 1974. Studies on performance of rose varieties on different rootstocks. Indian $\mathbf{J}$ Horti. 31:268-273.

Wickson, M. and Thimman, K. V. 1958. The antagonism of auxin and kinetin in apical dominance. Physiol Plant. 11: 62.

Zahir, Z. A., Asghar, H. N., and Arshad, M. 2001. Cytokinin and its precursors for improving growth and yield of rice. Soil Biol and Biochem. 33:405-408.

\section{How to cite this article:}

Prabhjit Kaur, H. S. Grewal, R. K. Dubey and Dhatt, K. K. 2020. The Influence of Plant Growth Regulator and Rootstocks on Budding in Greenhouse Rose (Rosa hybrida L.) cv. First Red. Int.J.Curr.Microbiol.App.Sci. 9(05): 2658-2665.

doi: https://doi.org/10.20546/ijcmas.2020.905.305 